Posey, Clayton V., sergeant, died of disease in France Prime, Wendell $\mathbf{F}$., second lieutenant, killed in action in France Racobs, Dan Bryan, private, died of wounds in France Rathsach, Herman H., private, died at Camp Dodge, Iowa Redden, Archie George, private, killed in action in France Reeder, Charles $H$., private, killed in action in France Rhodes, Glen E., corporal, killed in action in France Richter, Louis William, private, died of disease in France Robinson, Charles Franklin, corporal, died at Panama Canal Roeschke, Herman C., appr. seaman died at Great Lakes, Illinois Satterlee, Rathburn Edagr, private, died of wounds in France Schenk, Robert, cook died at Camp Kearney, California Schiller, Harold S., private, died at Fort Bayard, New Mexico Schmeelk, Henry Wm., private, died of disease in France Seiler, Barbara Loretta, nurse, died at Camp Dodge, Iowa Seney, Elmer P., chief petty officer, died at Spokane, Washington Severson, William Christian, lieutenat, killed in action in France Shumaker, Howard, Frank, private, died at Nitro, West Virginia Smith, Merwyn E., private, killed in action in France Steele, Fred F., private, died at Camp Dodge, Iowa Stekelenburg, John, private, killed in action in France Tawzer, Ralph W., private, died at Dallas, Texas Thompson, Thruce M., private, died of disease in France Tott, William H., private, died of disease in France Tubbs, Roy Vernon, private, died at Camp Dodge, Iowa Vander Burg, Henry, musician, died at Oakland, California Verstegen, Garrett, private, died of disease in France Virgil, Anton, private, killed in action in France White, Winfield March, first lieutenant, killed in action in France Whiting, A rthur Earl, private, died of disease in France Wink, Henry C., private, died of wounds in France Woodruff, William A., 3rd class fireman, died at Great Lakes, Illinois Zettle, Howard Philip, private, killed in action in France Zuruvak, Henry H., private, died in France (accident)

\title{
NEWS EXPECTED BY THE HORN TELEGRAPH
}

The Valley Mail, we hear, is on the way by ox teams, and may be expected in about ten days at this place.-The Frontier Guardian, Kanesville (Council Bluffs), Iowa, June 12, 1850. (In the Newspaper Division of the Historical, Memorial and Art Department of Iowa.) 
Copyright of Annals of Iowa is the property of State of Iowa, by \& through the State Historical Society of Iowa and its content may not be copied or emailed to multiple sites or posted to a listserv without the copyright holder's express written permission. However, users may print, download, or email articles for individual use. 